Egyptian Journal of Rabbit Science, 26(2): 135-154 (2016)

\title{
REPLACEMENT OF MORINGA STEMS INSTEAD OF CLOVER STRAW WITH OR WITHOUT MULTI ENZYMES (CAPLIX) IN GROWING RABBIT DIETS
}

\section{H.M. Sobhy' ; M.R.M. Ibrahim ${ }^{2}$; A.A.M. Soliman ${ }^{3}$;hanaa.F. Mohammadi ${ }^{4}$;} M.S.Abouskken ${ }^{5}$ and A. A. M. Ahmed ${ }^{4}$

1. Department of natural resources, Research Institute of African Studies. Cairo University, Giza, Egypt.

2. Animal Nutrition Research Department, Animal Production Research Institute, Agricultural Research Center,. El-Dokki, Giza, Egypt.

3. Animal Production Department, Faculty of Agriculture, Cairo University, Giza, Egypt.

4. Regional Center for Food and Feed, Agricultural Research Center, Giza, Egypt.

5. Environmental studies and Research Institute, Sustainble Department University of Sadat City, Monofeya, Egypt

A total number of 72 New Zealand White (NZW) growing rabbits of mixed sex, 6 weeks old of about 500 \pm 13.75 g average body weight were used to study the effect of different levels of Moringa stems without or with supplementation of caplix enzyme on rabbit performance, nutrients digestibility coefficient, caecum activity, carcass characteristics and economic efficiency. Rabbits were divided into 6 treatments; each containing 12 rabbits in 4 replicates (3 rabbits in each). Three substitution levels of Moringa stems, as well as, two levels without or with caplix were used in $3 \times 2$ factorial arrangement. Moringa stems levels were zero (control), 25 and 50\% instead of clover straw of the control diet, while the levels of caplix were 0 or $0.05 \%$ of diet. The experimental period was extended to 8 weeks.

These results obtained indicated that, replacing Moringa stems for clover straw at 25 and $50 \%$ in rabbit diets significantly $(P<0.05)$ improved $C P, E E, C F, N D F, A D F$ and $A D L$ digestibility as will as DCP and TDN values compared to the control group. Also, adding caplix to rabbit diets improved $(P<0.05)$ these nutrients digestibility as compared to the groups fed diets without caplix. Replacing Moringa stems by clover straw at 25 and $50 \%$ or adding caplix to rabbit diets resulted in an improvement $(P<$ $0.05)$ of caecum $p H$ and an increase $(P<0.05)$ in caecal VFAS 
concentration. There were significant $(P<0.05)$ increases in average daily $B W G$ and significant $(P<0.05)$ improvement in FCR with either replacing Moringa stems at a level of $25 \%$ or adding caplix to rabbit diets. Replacing Moringa stems by clover straw at 25 and $50 \%$ or adding caplix to rabbit diets increased $(P<0.05)$ dressing $\%$, edible giblets\% and total edible parts $\%$ in comparison to the control group. While there were insignificant differences in contents of moisture, CP and EE\% among the different tested experimental groups. Replacing Moringa stems by clover straw at all tested levels in rabbit diets either without or with caplix increased the economic efficiency as compared to the control group.

Conclusively, these results showed that Moringa stems can be used instead of clover straw (up to 50\%) in growing rabbit diets with caplix (0.05\%) without negative effects on growth performance under Egyptian environmental conditions.

Keywords: Moringa stems, caplix, growth performance, digestion, carcass characteristics.

In developing countries such as Egypt and South Africa, shortage of feeds and its high cost are major problems for shortage of animal protein sources in human food. Limited land resources and the high competition between human and livestock for high quality grain and protein supplements are major contributors to nutrient deficiencies. Therefore, efforts have been made towards solving feeds shortage by improving the conventional sources and investigating more unconventional feeds for availability in animal feed.

Moringa oleifera lam commonly known as "The Miracle Tree or Horseradish Tree" is the best known and most widely distributed species of Moringaceae family, having an impressive range of medicinal uses with high nutritional value throughout the world. Moringa trees are native to India, Pakistan, Asia and Africa, where it can be grown in a variety of soil conditions preferring well-drained sandy or loamy that is slightly alkaline (Kristin, 2000 and Luqman et al., 2012). Several biological properties ascribed to various parts of this tree, the leaves have been reported to be a valuable source of â-carotene (precursor of vit. A), vitamins (B-complex, C, D and K) beside some important macro- elements as calcium, potassium. Zinc, iron, copper and selenium (Dorga, et al., 1975 and Booth and Wickens, 1988). Moreover, it was reported that Moringa oleifera leaves and fruits prevent effectively morphological changes and oxidative damage in human and animals by enhancing the activities of 
antioxidant enzymes, reducing the intensity of lipid peroxidation and inhibiting generation of free radicals (Sreelather and Padma, 2009 and Osman et al., 2012)

In Egypt, great attention has been given by plant breeders to implant Moringa oleifera imported seeds in agricultural and newly reclaimed lands for human and animal uses. Little studies have been conducted on lactating cattle, laying hens and rabbits, with either fresh (green fodder) or dry leaves. However, most people in Egypt, are not aware of the potential benefits of moringa, beside the expensive price of its products (about 70.000 US\$/ ton dry leaves). ElBadawi et al. (2014).

Adding enzymes to diets of non ruminant animals, particularly poultry, has become more common in recent years (Campbell and Bedford, 1992). Current developments in this area include digestibility of starch and non-starch polysaccharides in cereals. The exogenous enzyme supplementations are well documented (Bedford and Classen 1992). These enzymes can partially hydrolyze non soluble protein (NSP), reduce the viscosity of gut contents, and result in improvements in nutrient absorption.

Several studies have been attempted for incorporating exogenous enzymes into rabbit diets to improve nutrients availability. Eiben et al. (2004), testing cellulase, got improvements in FCR and mortality of rabbits weaned at 23 days of age, whereas ADG was unaffected. It is interesting to note that in some trials, enzymes improved fiber digestibility (Bolis et al.,1996 and Fernandez et al., 1996). The latter authors got significant improvements when cellulase and enzyme pool (xylanase, beta-glucanase, alpha-gluccosidase, pentosanase, myloglucosidase, acid and neutral protease) was added on NDF (+5\%) and ADF $(+13 \%)$ digestibilities.

Therefore, the main objective of this investigation was to evaluate the effect of replacing Moringa stems for clover straw either without or with adding multi enzymes (caplix) in growing rabbit diets on growth performance, nutrients digestibility, carcass characteristics and blood parameters.

\section{MATERIALS AND METHODS}

The present experiment was carried out at the Environmental Studies Institute farm belonging to Sadat City University, Monofeya, Egypt, during November and through December, 2014. The chemical analysis was conducted at the laboratory Regional Center For Food and Feed and Animal Production Research Institute. The Moringa oleifera by-products were obtained from the privet farm belonging to El-Minia Governorate. The stems were separate 
manually and the crushing and milling operations were carried out using a local hammer mill machine at Agricultural Engineering Research Institute, (AENRI). The fine products of stems were separately pooled each other and on open doordried to constant moisture levels, and there after bagged for experimental procedures.

A total number of 72 New Zealand White (NZW) growing rabbits mixed sex, six weeks old with $500 \pm 2.5$ g average body weight were used to study the effect of different Moringa stems levels without or with supplementation of multi-enzymes (caplix) on rabbit growth, nutrients digestibility coefficient, carcass characteristics and economic efficiency. Rabbits were randomly divided into 6 equal groups with four replicates (3 rabbits each). The main groups of rabbits were fed diets containing different levels of Moringa stems instead stem clover straw at levels 0, 25 and 50\% throughout the experimental period (from 6-13 weeks of age) as shown in Table 1 . In each group, diets were fed to the rabbits either un-supplemented or supplemented with caplix $(0$ or $0.05 \%$ of diets). The diets were formulated to cover the requirement of growing rabbits according to NRC (1977). Chemical composition of Moringa stems and clover straw is shown in Table 2. Caplix compound is a multiple enzyme product. Each gram comprises cellulase $100000000 \mathrm{IU}$, amylase $250000 \mathrm{IU}$, arabinase 7000 IU, pectinase $30000 \mathrm{IU}$, protease $400000 \mathrm{IU}$, lipase $6500 \mathrm{IU}$, xylanase 1500000 IU, beta glucanase $10000 \mathrm{IU}$ and alpha galactosidase 10000 IU. Diets were offered to the rabbits ad-libtum and fresh water was available all the time during the experiment. Individual live body weight, feed intake and feed conversion ratio were recorded weekly, then calculated monthly and throughout the whole period (8 weeks)

Digestibility trials were carried out using four rabbits from each experimental group at the last week of the experiment. Rabbits for each group were housed in metabolism cages where feces and urine were collected separately four consecutive days. Proximate analysis of the diets, feces and meat were carried out according to the methods of A.O.A.C.( 2002). Neutral detergent fiber (NDF), acid detergent fiber (ADF), Acid detergent Lignine (ADL) Hemicellulose, Cellulose and Lignine were analyzed according to Van-Soest et al., (1991).

At the end of experimental period, four mix sex rabbits were randomly taken from each group and fasted for 12 hours before slaughter according to Blasco et al., (1993). Fasted rabbits were housed in separate cages and kept under the same managerial and hygienic condition. Rabbit meat samples 
Table 1. Composition and determined analysis of the experimental diets

\begin{tabular}{|l|c|c|c|c|c|c|}
\hline \multirow{2}{*}{ Ingredients } & \multicolumn{5}{|c|}{ Level of Moringa stems replacement \% } \\
& \multicolumn{5}{|c|}{ Oaplix addition } & \multicolumn{2}{c|}{$\mathbf{5 0}$} \\
& $(-)$ & $(+)$ & $(-)$ & $(+)$ & $(-)$ & $(+)$ \\
\hline Barley 2 rowed & 7.6 & 7.55 & 8.10 & 8.05 & 7.85 & 7.80 \\
Clover straw & 30.00 & 30.00 & 22.50 & 22.50 & 15.00 & 15.00 \\
Soybean meal (44\%) & 16.32 & 16.32 & 16.32 & 16.32 & 16.32 & 16.32 \\
Moringa stems & 0.00 & 0.00 & 7.50 & 7.50 & 15.00 & 15.00 \\
Corn gluten meal & 6.60 & 6.60 & 6.30 & 6.30 & 6.10 & 6.10 \\
Yellow corn & 28.80 & 28.80 & 28.80 & 28.80 & 29.50 & 29.50 \\
Calcium phosphate, dibasic & 1.50 & 1.50 & 1.45 & 1.45 & 1.35 & 1.35 \\
Sunflower oil, refined & 2.50 & 2.50 & 2.50 & 2.50 & 2.50 & 2.50 \\
Sugar cane molasses & 3.00 & 3.00 & 3.00 & 3.00 & 3.00 & 3.00 \\
Coarse wheat bran & 1.40 & 1.40 & 1.40 & 1.40 & 1.40 & 1.40 \\
Salt ( Na cl ) & 0.35 & 0.35 & 0.35 & 0.35 & 0.35 & 0.35 \\
Premix* & 0.30 & 0.30 & 0.30 & 0.30 & 0.30 & 0.30 \\
Limestone & 1.15 & 1.15 & 1.00 & 1.00 & 0.85 & 0.85 \\
L-Lysine HCL 98\% & 0.15 & 0.15 & 0.15 & 0.15 & 0.15 & 0.15 \\
Methionine & 0.33 & 0.33 & 0.33 & 0.33 & 0.33 & 0.33 \\
Enzyme(Caplix) & 0.00 & 0.05 & 0.00 & 0.05 & 0.00 & 0.05 \\
\hline Total & $\mathbf{1 0 0}$ & $\mathbf{1 0 0}$ & $\mathbf{1 0 0}$ & $\mathbf{1 0 0}$ & $\mathbf{1 0 0}$ & $\mathbf{1 0 0}$ \\
\hline Determined analysis & & & & & & \\
\hline CP\% & 16.87 & 16.88 & 16.82 & 16.82 & 16.82 & 16.79 \\
DE (Kcal/Kg)** & 2500.8 & 2500 & 2517.9 & 2517.9 & 2538.7 & 2538 \\
CF\% & 14.23 & 14.23 & 14.56 & 14.56 & 14.86 & 14.86 \\
EE\% & 4.43 & 4.43 & 4.46 & 4.46 & 4.50 & 4.50 \\
Ca\% & 0.84 & 0.84 & 0.84 & 0.84 & 0.84 & 0.84 \\
P\% & 0.54 & 0.54 & 0.55 & 0.54 & 0.54 & 0.54 \\
Methionine\% & 0.62 & 0.62 & 0.61 & 0.61 & 0.61 & 0.61 \\
Lysine\% & 0.77 & 0.77 & 0.77 & 0.77 & 0.77 & 0.77 \\
\hline Vitamin and mine
\end{tabular}

*Vitamin and minerals premix at level of $0.3 \%$ of diet supplies the following per $\mathrm{Kg}$ of diet: Vit. A 12000 IU, Vit. D3 2000 IU, Vit E $10 \mathrm{mg}$, Vit. K3 2mg, Vit B 1 mg, Vit B ${ }_{2} 5 \mathrm{mg}$, Vit.B $_{6} 1.5 \mathrm{mg}$, Vit. $\mathrm{B}_{12} 10 \mathrm{mg}$; Niacin $30 \mathrm{mg}$, Pantotheanic acid $10 \mathrm{mg}$; Folic acid 1mg, Choine $250 \mathrm{mg}$, Biotin $50 \mathrm{mg}$, Copper 5mg, Manganese $60 \mathrm{mg}$, Zinc 50mg, Iron 30mg, Iodine $0.3 \mathrm{mg}$ Selenium $0.1 \mathrm{mg}$ and Cobalt $0.1 \mathrm{mg}$.

**Calculated according to Fernandez et al. (2004). 
Table 2. Chemical analysis of clover straw and Moringa stems (\% on DM basis)

\begin{tabular}{|l|c|c|}
\hline Items (\%) & $\begin{array}{c}\text { Moringa } \\
\text { stems }\end{array}$ & $\begin{array}{c}\text { Clover } \\
\text { straw }\end{array}$ \\
\hline DM & 92.87 & 90.00 \\
\hline OM & 84.99 & 81.50 \\
\hline CP & 7.00 & 6.00 \\
\hline CF & 43.08 & 39.00 \\
\hline EE & 1.10 & 0.80 \\
\hline Ash & 7.88 & 8.50 \\
\hline NFE & 40.94 & 45.70 \\
\hline NDF & 53.71 & 54.50 \\
\hline ADF & 48.78 & 48.70 \\
\hline ADL & 8.42 & 13.00 \\
\hline Hem. & 4.93 & 5.80 \\
\hline Cell. & 40.36 & 35.57 \\
\hline Lig. & 7.35 & 9.60 \\
\hline Ca & 0.92 & 0.00 \\
* Calculated digestible energy (DE Kcal/gm) $=2823-40.8^{*}$ ADF $-25.7 \mathrm{ADL}+47.4 \mathrm{CP}$, \\
According to Fernandez et al. $(2004)$
\end{tabular}

included whole edible meat, including inter muscular fat and tendons. Liver, kidneys and lungs were separated and analyzed as 'rabbit offal'. Rabbit meat samples (a part of the hind leg), each sample was hand-boned and dissected from the fat surface, and the lean part was then finely minced. Samples were prepared for chemical analysis in duplicate for moisture, protein, fat and ash content.

The cecum was immediately exteriorized and caecal contents were removed. The contents from rabbits fed the same ration were pooled and taken to the laboratory for processing within $10 \mathrm{~min}$ of collection. A fresh sample strained through four layers of cheesecloth, the filtrate was immediately subjected to $\mathrm{pH}$ determination with a combination electrode. A portion of the filtrate was sampled and frozen at $-20^{\circ} \mathrm{C}$ for determination of ammonia- $\mathrm{N}$ and volatile fatty acid (TVFA"s) content. Samples for ammonia-N determination were acidified with a solution of $0.2 \mathrm{M}$ hydrochloric acid $(1 \mathrm{ml} / \mathrm{ml})$.

An input - output analysis and economic efficiency were calculated. The cost of 1 kilogram of growth was determined for each of the experimental diets according to the prevailing cost of ingredients in Egypt at the time of the experiment. Economic efficiency of each diets was defined as LE returned for 1 LE invested in feed. Economic efficiency was calculated by the following equation: 
Economic efficiency $=($ Selling price of one $\mathrm{kg}$ live body weight - Feeding cost of one live body weight / Feeding cost of one kg live body weight $) \times 100$

All data were subjected to analysis of variance using the generally linear models GLM Procedure of SAS, 2002 and differences obtained upon statistical analysis were compared using Duncan Multiple Range Test (Duncan, 1955).

\section{RESULTS AND DISCUSSION}

\section{Nutritional evaluation of experimental clover straw and Moringa stem}

Proximate analysis of the tested Moringa stem (on DM basis) compared to clover straw is shown in Table 2. The obtained data showed that Moringa stems was higher in contents of DM, OM, CP, CF, EE, ADF, cellulose (Cell.), Ca and DE, than those in clover straw. The values being 92.87 vs. $90 \% ; 84.99$ vs. 81.50 $\% ; 7.00$ vs. $6.00 \% ; 43.08$ vs. $39.00 \% ; 1.10$ vs. $0.80 \% ; 48.78 v s .48 .70 \% ; 40.36$ vs. $35.57 \%$; 0.92 vs. $0.00 \%$; 0.21 vs. $0.00 \%$ and $948.18 v s .783 .00 \mathrm{Kcal} / \mathrm{Kg}$ for DE, respectively. However, clover straw was higher in ash, NFE, NDF, ADL, hemicellulose (Hemi.) and Lignin (Lig.). The values were being 8.5 vs. $7.88 \%$; 45.70 vs. $40.94 \%$; 54.50 vs. $53.71 \%$; 13.13 vs. $8.42 \%$; 5.80 vs. 4.93 and $9.60 v s$. $7.35 \%$, respectively. In this connection Safwat et al. (2014) reported that Moringa olifera (stems and leaves) contain 23.94\% DM, 21.04\% CP, $15.28 \%$ $\mathrm{CF}, 31.32 \% \mathrm{NDF}, 26.88 \% \mathrm{ADF}, 6.25 \% \mathrm{EE}$ and $8.89 \%$ ash. In this connection Mahmoud (2013) found that moringa stems contain 91.65\% DM, 90.82\% OM, 9.18\% ash, $16.14 \% \mathrm{CP}, 0.87 \% \mathrm{EE}, 30.53 \% \mathrm{CF}, 43.28 \% \mathrm{NFE}, 74.45 \% \mathrm{NDF}$, $59.66 \%$ ADF, $11.20 \%$ ADL, $48.46 \%$ cellulose and $14.79 \%$ hemicellulose.

\section{Effect of Moringa stems levels without or with caplix on: a. Digestion coefficient and nutritive values}

The digestion coefficients of nutrients as affected by different levels of Moringa stems without and with caplix are summarized in Table 3. It could be noticed that replacement Moringa stems for clover straw in rabbit diets at levels $25 \%$ and $50 \%$ increased $(\mathrm{P}<0.05)$ the digestibility of $\mathrm{CP}, \mathrm{EE}, \mathrm{CF}, \mathrm{NDF}, \mathrm{ADF}$, ADL, hemicellulose, cellulose, lignin and DCP compared to the control group. The recorded values were 73.48 and $72.69 v s$ 68.73\%.; 62.17 and $62.75 v s$. $58.63 \%$; 47.06 and $45.28 v s .38 .47 \% ; 42.36$ and 41.42 vs. $37.03 ; 43.73$ and 42.92 vs. $38.81 \%$; 28.27 and 26.09 vs. $22.09 \%$; 37.11 and 35.54 vs. $29.78 \%$; 45.06 and 43.84 vs. $41.37 \% ; 27.95$ and 26.29 vs. $21.68 \%$ and 12.36 and 12.20 vs. $11.60 \%$, respectively. Besides, there were significant increases $(\mathrm{P}<0.05)$ in nutritive 
values as TDN with replacing Moringa stems for clover straw at level $25 \%$ in rabbit diets compared to either the control diet or $50 \%$ moringa stems diet, being 65.41 vs. 61.76 and 59.99\%. In this connection Mahmoud (2013) fed lambs three experimental rations, the first group was fed rations containing clover hay (1\%from life body weight plus concentrate feed mixture (CFM) as a control rations (R1). While the other two lambs groups were fed on clover hay plus $25 \%$ Moringa oleifera stems from CFM (R2) and 25\% Moringa oleifera stems from clover hay plus CFM (R3). Results indicated that highest $(\mathrm{P}<0.05)$ of most nutrients digestibility and nutritive values were recorded for control ration (R1), while R2 showed the lowest values and R3 had intermediated values.

Regardless, the effect of Moringa stems, the results revealed that adding caplix to rabbit diets containing Moringa stems improved the nutrients digestibility and nutritive values compared to the diets without caplix. The results here in coincided with those reported by Abd El-Latif et al. (2008), who found that rabbits fed $10 \% \mathrm{CF}$ and provided with enzymes recorded better $(\mathrm{P}<0.05)$ values of $\mathrm{DM}, \mathrm{CP}$ and $\mathrm{CF}$ digestibility. The improvement in nutrient digestibility may be due to adding a multiple enzymes product (Optizyme), which contain protease, amylogulcosidase, xylanases, glucannase and hemicellulase, since monogastric animal diets suffer from under utilization of nutrients due to absence of enzymes necessary for hydrolyzing non-starch polysaccharides in the foregut.

Concerning the effect of the interaction between Moringa stems and caplix, the results showed that feeding rabbits the diet containing 25\% Moringa stems with caplix had the highest values $(\mathrm{P}<0.05)$ of most nutrients digestibility and nutritive values compared to the other experimental groups. While, the lowest values of those parameters were recorded with rabbits group fed the control diet without caplix.

\section{b-Caecum activity}

The effect of Moringa stems levels and adding caplix on caecum activity is shown in Table 4. It could be noticed that caecum weight, caecum length and TVFS concentration were caecal juice significantly $(\mathrm{P}<0.05)$ increased with replacing Moringa stems for clover straw at levels 25 and $50 \%$ in rabbit diets compared to the control group. The recorded values were 10.38 and $10.50 \mathrm{vs}$. $9.77 \mathrm{~g}, 11.62$ and 11.75 vs. $10.68 \mathrm{~cm}$ and 4.08 and 4.17 vs. $3.68 \mathrm{mq} / 100 \mathrm{ml}$, respectively. Besides, there was an improvement $(\mathrm{P}<0.05)$ in caecum $\mathrm{pH}$ with replacing Moringa stems at these tested levels, being 6.76 and 6.74 vs. 7.05 . In 
Table 4: Caecum activity of growing White New Zealand rabbits fed the experimental diets. (Means $\pm \mathrm{SE}$ ).

\begin{tabular}{|c|c|c|c|c|}
\hline Items & $\begin{array}{l}\text { Caecum } \\
\text { weight } \\
\text { (g) }\end{array}$ & $\begin{array}{l}\text { Caecum } \\
\text { length, } \\
(\mathrm{cm})\end{array}$ & $\begin{array}{c}\text { Caecum } \\
\text { pH }\end{array}$ & $\begin{array}{c}\text { TVF'S } \\
\text { caecal juice } \\
\text { in } \\
(\mathbf{m q} / \mathbf{1 0 0 m l})\end{array}$ \\
\hline \multicolumn{5}{|c|}{ Effect of replacing Moringa stems levels, \% } \\
\hline $\mathbf{0}$ & $9.77^{\mathrm{b}}$ & $10.68^{\mathrm{b}}$ & $7.05^{\mathrm{a}}$ & $3.68^{\mathrm{b}}$ \\
\hline 25 & $10.38^{\mathrm{a}}$ & $11.62^{\mathrm{a}}$ & $6.76^{b}$ & $4.08^{\mathrm{a}}$ \\
\hline 50 & $10.50^{\mathrm{a}}$ & $11.75^{\mathrm{a}}$ & $6.74^{\mathrm{b}}$ & $4.17^{\mathrm{a}}$ \\
\hline $\mathbf{S E}$ & \pm 0.1728 & \pm 0.2569 & \pm 0.0642 & \pm 0.0595 \\
\hline \multicolumn{5}{|c|}{ Effect of Caplix level,\% } \\
\hline 0.00 & $9.43^{\mathrm{b}}$ & $10.43^{b}$ & $7.04^{\mathrm{a}}$ & $3.58^{\mathrm{b}}$ \\
\hline $\begin{array}{l}0.05 \\
\text { SE }\end{array}$ & $\begin{array}{l}11.00^{\mathrm{a}} \\
\pm 0.00\end{array}$ & $\begin{array}{c}12.27^{\mathrm{a}} \\
\pm 0.2098\end{array}$ & $\begin{array}{c}6.66^{\mathrm{b}} \\
\pm 0.0524\end{array}$ & $\begin{array}{c}4.37^{\mathrm{a}} \\
\pm 0.0486\end{array}$ \\
\hline \multicolumn{5}{|c|}{ Effect of Moringa stems X Caplix, \% } \\
\hline $\mathbf{0}(-)$ & $9.04^{\mathrm{e}}$ & $9.85^{\mathrm{d}}$ & $7.30^{\mathrm{a}}$ & $3.15^{\mathrm{e}}$ \\
\hline O (+) & $10.50^{\mathrm{bc}}$ & $11.50^{\mathrm{bc}}$ & $6.79^{\text {bcd }}$ & $4.21^{\mathrm{bc}}$ \\
\hline $25(-)$ & $9.40^{\mathrm{de}}$ & $10.48^{\mathrm{cd}}$ & $6.99^{b}$ & $3.64^{\mathrm{d}}$ \\
\hline $25(+)$ & $11.35^{\mathrm{a}}$ & $12.75^{\mathrm{a}}$ & $6.53^{\mathrm{d}}$ & $4.52^{\mathrm{a}}$ \\
\hline $50(-)$ & $9.85^{\mathrm{cd}}$ & $10.95^{\mathrm{cd}}$ & $6.83^{\mathrm{bc}}$ & $3.96^{\mathrm{c}}$ \\
\hline $50(+)$ & $11.15^{\mathrm{ab}}$ & $12.55^{\mathrm{ab}}$ & $6.65^{\mathrm{cd}}$ & $4.37^{\mathrm{ab}}$ \\
\hline SE & \pm 0.2444 & \pm 0.3630 & \pm 0.0910 & \pm 0.0840 \\
\hline
\end{tabular}

a, b, c ......Means within the same column with different letters are significantly different $(\mathrm{P}<0.05)$

(-) without Caplix

(+) with Caplix

this connection Mahmoud (2013) reported no significant differences were observed among tested rations (control diet, clover hay plus 25\% Moringa olifera stems from concentrate feed mixture and 25\% Moringa olifera stems from clover hay plus concentrate mixture) for concentration of TVFS before and at all times after feeding. Also, $\mathrm{pH}$ values and ammonia concentration before and 6 hours after feeding recorded insignificant differences.

Regardless the effect of Moringa stems levels, the results revealed that adding caplix to rabbit diets increased $(\mathrm{P}<0.05)$ caecum weight, caecum length, Caecum $\mathrm{pH}$ and TVFS caecal juice compared to the diet without caplix, being 11.00 vs. $9.43 \mathrm{~g}, 12.27$ vs. $10.43 \mathrm{~cm}, 6.66$ vs. 7.04 and 4.37 vs. $3.58 \mathrm{mq} / 100 \mathrm{ml}$, respectively. This improvement may be due to enhancing effect of caplix enzymes on microflora growth in gut and caecum as will as the increase in volatile fatty acids production and organic matter digestibility (Abd-El-Latif 
et al., 2008). Moreover, adding a multiple enzymes product (optizym) which contain protease, amylouglcosidase, xylanases, $\beta$-glucannase, cellulase and hemicellulase to monogastric animal diets suffer from under utilization of nutrients due to absence of enzymes necessary for hydrolyzing non-starch polysaccharides in the foregut, reduces the viscosity of intestinal content and improves nutrients absorption (Sullivan, 1987).

Results concerning effect of Moringa stems $x$ caplix showed that the highest $(\mathrm{P}<0.05)$ values of caecum weight, caecum length and TVFS in caecal juice and best $(\mathrm{P}<0.05)$ values of caecum $\mathrm{pH}$ were noticed with rabbits group fed 25\% Moringa stems diets with caplix, being $11.35 \mathrm{~g}, 12.75 \mathrm{~cm}, 4.52 \mathrm{mq} / 100 \mathrm{ml}$ and 6.53, respectively. While the lowest values were recorded with rabbits group fed the control diet without caplix, being $9.04 \mathrm{~g}, 9.85 \mathrm{~cm}, 3.15 \mathrm{mq} / 100 \mathrm{ml}$ and 7.3 , respectively.

\section{c- Growth performance}

The results of Table 5 revealed that replacing Moringa stems for clover straw in rabbit diets at level $25 \%$ increased $(\mathrm{P}<0.05)$ average FBW and daily BWG and improved FCR in comparison to the control group. The values were 2006.00 vs. $1894.10 \mathrm{~g}$ and 27.00 vs. $25.11 \mathrm{~g} \mid \mathrm{d}$ and 3.12 vs. $3.29 \mathrm{~g}$, respectively. Besides there were significant increases $(\mathrm{P}<0.05)$ in values of average FBW and daily BWG with replacing Maringa stems for clover straw at level 50\% in rabbit diets compared to the control group, being 2034.33 vs. $1894.10 \mathrm{gm}$ and 27.44 vs. $25.11 \mathrm{~g} / \mathrm{d}$, respectively.

Generally adding Moringa stems to rabbit diets at the tested levels 25 and 50\% of clover straw ( 7.5 and 15 of the diet) improved the growth rate. This servation is in good agreement with those reported by Talha, 2013 who noticed that Moringa leaf meal significantly $(\mathrm{P}<0.05)$ increased rabbit's daily weight gain. Moreover, Ibrahim et al. (2014) found that daily weight gain significantly increased in the rabbits fed 0.2 or $0.4 \%$ Moringa seeds compared to the control group.

In broilers, El-Tazi (2012) reported that Ross broiler chicks fed the diet containing Moringa oleifera leaf meal at levels of 3,5 and $7 \%$ gained significantly higher and superior feed conversion rate than birds fed the control diet. Also in lambs Mohmoud (2013) found that rations contained Moringa oleifera stems (25\% Moringa oleifera stems from clover hay) achieved higher feed efficiency than control rations.

Regardless the effect of Moringa stems, there were significant $(\mathrm{P}<0.05)$ increases in averages values of FBW, daily BWG and FI and an improvement 
$(\mathrm{P}<0.05)$ in FCR with adding caplix in rabbit diets compared to those groups fed diets without caplix. The recorded values were 2135.10 vs. $1821.19 \mathrm{~g}, 29.29$ vs. $23.74 \mathrm{~g}|\mathrm{~d}, 92.36 \mathrm{vs} .79 .74 \mathrm{~g}| \mathrm{d}$ and 3.15 vs. $3.36 \mathrm{~g}$, respectively. The results here are in are good agreement with those reported by Abd El-Latif et al. (2008) who found that feed conversion efficiency was improved for rabbits fed 10 or $13 \% \mathrm{CF}$ with providing enzymes compared to rabbits fed these diets without enzymes.

The effect of Moringa stems x caplix showed that the best values $(\mathrm{P}<0.05)$ of average FBW, average daily BWG and FCR were noticed with rabbits group fed 25\% Moringa stems diet with caplix. The values were $2225.38 \mathrm{~g}, 30.83 \mathrm{~g} \mid \mathrm{d}$ and $2.96 \mathrm{~g}$, respectively. In adverse the worst values of averages FBW, daily BWG and FI were found with rabbit's group fed the control diet without caplix $(1777.27 \mathrm{~g}, 22.99 \mathrm{~g} \mid \mathrm{d}$ and $76.32 \mathrm{~g} \mid \mathrm{d})$. Besides, the worst FCR values were with rabbits group fed 50\% Moringa stems diets without caplix (3.42).

\section{d-Carcass characteristics}

Results concerning carcass characteristics of rabbits as affected by the experimental diets are shown in Table 6. It could be noticed that replacing Moringa stems for clover straw at levels 25 or $50 \%$ in rabbit diets increased $(\mathrm{P}<0.05)$ carcass weight, dressing \%, liver weight, kidney weight, heart weight, edible giblets and total edible parts\% compared to the control group. The obtained values were 1046.00 and 1060.00 vs. 933.75 g.; 50.85 and 51.11 vs. 49.61\%.; 79.00 and 81.75 vs. 66.00 g.; 15.88 and 16.00 vs. 13.13 g.; 7.63 and 7.50 vs. 6.00 ; 5.02 and 5.09 vs. $4.53 \mathrm{~g}$ and 56.32 and 56.42 vs. $54.31 \%$, respectively. The observations here are in agreement with those reported by Dougnon et al. (2012) and El-Tazi (2012) who found that rabbit's carcass yield ranged from 60.6 to $64.5 \%$ and pellets of Moringa meal can be substituted at a level of $15 \%$ to the commercial feed with a positive effects on carcass characteristics of rabbits. In broilers, El-Tazi (2012) cited that inclusion of Moringa olifera leaf meal ( MOLM) in broiler diets up to 3 or $7 \%$ significantly $(\mathrm{P}<0.05)$ improved hot and cold eviscerated carcass weight, dressing percentage, breast and drumstick percentages and tenderness and juiciness scores for both breast and thigh meat.

Regardless the effect of Moringa stems levels, the values of all tested carcass characteristics were higher $(\mathrm{P}<0.05)$ with adding caplix to rabbit diets compared to those groups fed diets without caplix. The recorded values were 1160.08 vs. 866.42 gm for carcass weight, 54.32 vs. $46.73 \%$ for dressing, 86.17 vs. $65.00 \mathrm{~g}$ for liver weight, $17.42 \mathrm{vs} .12 .58 \mathrm{~g}$ for kidney weight, $8.00 \mathrm{vs.} 6.08 \mathrm{~g}$ 
اين جدول 7 
for heart weight, 5.22 vs. $4.50 \%$ for edible giblets and 59.54 vs. $51.23 \%$ for total edible parts.

Data concerning the effect of Moringa stems $x$ caplix revealed that the highest $(\mathrm{P}<0.05)$ values of all tested carcass characteristics were recorded with rabbits group fed $25 \%$ Moringa stems diets with caplix. Nevertheless, the lowest $(\mathrm{P}<0.05)$ values were recorded with that group fed the control diet without caplix.

\section{e-Chemical composition of rabbit meat}

Values of chemical composition of the experimental rabbits meat (moisture, CP and EE) are illustrated in Table 7. It is worthy to notice that neither replacement Moringa stems levels nor adding caplix affect significantly meat content of moisture, $\mathrm{CP}$ and EE. Accordingly, the interaction effect of Moringa stems levels and caplix was insignificant. These results are disagreed with those reported by Nuhu (2010) who found that offering weaner rabbits a diet containing Moringa leaf meal at a level of $15 \%$ significant $(\mathrm{P}<0.05)$ increased crude protein of meat and reduced ether extract of meat when compared to the control diet. In broilers chickens, Zanu et al (2012) reporter that incorporation Moringa leaf meal in rabbit diets at levels 5, 10 and 15\% affected $(\mathrm{P}<0.05)$ the moisture, crude protein and crude fibber of meat in comparison to the control group ( $0 \%$ Moringa leaf meal).

\section{$f$ - Economic efficiency}

The final body weight, length of the growing period and feeding cost are generally among the most important factors involved in achieving maximum efficiency of meat production. The effect of treatments on economic efficiency of meat production is presented in Table 8. It should be pointed that the economic efficiency value was calculating based on the price of selling rabbit which was $29 \mathrm{LE} / \mathrm{kg}$ live body weight.

Results indicated that replacing Moringa stems for clover straw at levels of 25 and 50\%, without or with caplix in rabbit diets improved the economic efficiency (EE), compared to the control groups. The relative economic efficiency (REE) was improved at 100, 100.84 and $112.08 \%$, for diets without caplix, and $129.49,167.98$ and $148.60 \%$ for diets with caplix, respectively. The improvement may be due to the lower price of Moringa stems and better feed conversion for these diets.

Conclusively, these results showed that Moringa stems can be used instead of clover straw (up to 50\%) in growing rabbit diets with caplix $(0.05 \%)$ without negative effects on growth performance under Egyptian environmental conditions. 
Table 7. Effects of the experimental diets on rabbit meat analysis ( $\%$ fresh weight basis) (Means $\pm \mathrm{SE}$ ).

\begin{tabular}{|c|c|c|c|c|}
\hline Items & Moisture, $\%$ & DM & $\mathbf{C P}, \%$ & EE, \% \\
\hline \multicolumn{5}{|c|}{ Effect of replacing Moringa stems levels, \% } \\
\hline $\mathbf{0}$ & 68.68 & 31.33 & 24.14 & 3.15 \\
\hline 25 & 68.57 & 31.43 & 24.08 & 3.13 \\
\hline 50 & 68.74 & 31.27 & 24.05 & 3.12 \\
\hline SE & \pm 0.1639 & \pm 0.1639 & \pm 0.2177 & \pm 0.0578 \\
\hline \multicolumn{5}{|c|}{ Effect of Caplix level, \% } \\
\hline 0.00 & 68.67 & 31.33 & 24.04 & 3.15 \\
\hline 0.05 & 68.65 & 31.35 & 24.13 & 3.11 \\
\hline SE & \pm 0.134 & \pm 0.134 & \pm 0.178 & \pm 0.047 \\
\hline \multicolumn{5}{|c|}{ Effect of Moringa stems X Caplix, \% } \\
\hline O (-) & 68.71 & 31.29 & 24.03 & 3.16 \\
\hline $\mathbf{0}(+)$ & 68.64 & 31.36 & 24.24 & 3.13 \\
\hline $25(-)$ & 68.53 & 31.47 & 24.06 & 3.15 \\
\hline $25(+)$ & 68.61 & 31.39 & 24.10 & 3.11 \\
\hline $50(-)$ & 68.76 & 31.24 & 24.04 & 3.14 \\
\hline $50(+)$ & 68.71 & 31.29 & 24.06 & 3.10 \\
\hline SE & \pm 0.232 & \pm 0.232 & \pm 0.310 & \pm 0.082 \\
\hline
\end{tabular}

(-) Without Caplix

(+) With Caplix

Table 8.Economic efficiency (EE) of using Moringa stems and caplix level in diets of rabbits and their interaction, during the whole period (6-13 weeks old).

\begin{tabular}{|l|c|c|c|c|c|c|}
\hline \multirow{2}{*}{ Items } & \multicolumn{7}{|c|}{ Replacing Moringa stem levels (\%) } \\
\cline { 2 - 7 } & \multicolumn{2}{|c|}{ 0(Control) } & \multicolumn{2}{c|}{$\mathbf{2 5}$} & \multicolumn{2}{c|}{ Caplix addition } \\
\cline { 2 - 7 } & \multicolumn{7}{|c|}{$\mathbf{( + )}$} & $\mathbf{( - )}$ & $\mathbf{( + )}$ & $\mathbf{( - )}$ & $\mathbf{( + )}$ \\
\cline { 2 - 7 } Total FI/rabbit, kg & 4.274 & 4.967 & 4.320 & 5.110 & 4.801 & 5.439 \\
\hline Price 1kg FI & 2.695 & 2.702 & 2.689 & 2.706 & 2.683 & 2.690 \\
\hline Feed cost/ rabbit & 11.518 & 13.421 & 11.617 & 13.828 & 12.881 & 14.633 \\
\hline Total cost(LE)(a) & 38.018 & 39.921 & 38.117 & 40.328 & 39.381 & 41.133 \\
\hline BW & 1.7773 & 2.0109 & 1.7866 & 2.2254 & 1.8997 & 2.169 \\
\hline Cost/kg BW (L.E) & 21.39 & 19.85 & 21.33 & 18.12 & 20.73 & 18.96 \\
\hline Total revenue (LE)(b) & 51.54 & 58.32 & 51.81 & 64.54 & 55.09 & 62.87 \\
\hline Net revenue(L.E) & 13.52 & 18.40 & 13.69 & 24.12 & 15.71 & 21.74 \\
\hline EE (c) & 0.356 & 0.461 & 0.359 & 0.598 & 0.399 & 0.529 \\
\hline REE(d) & 100 & 129.49 & 100.84 & 167.98 & 112.08 & 148.60 \\
\hline
\end{tabular}

(a) Including fixed cost (26.50L.E/rabbit), (b) Assuming that the selling price \{is (29) L.E\},

(C) Net revenue per unit total cost, (d) Considering the economic efficiency (EE) of the control diet without caplix $=100 \%$. (-) Without caplix, $\quad(+)$ with caplix at level $0.05 \%$ 


\section{REFERANCES}

Abd El-Latif, S.A.; Kh.A., Mohammed; Kawsar A. Ghaly and Maha A. Abd El-Latif (2008). Effect of using commercial enzymes on performance and some metabolic functions of rabbits fed grade levels of crude fiber. Egypt. Poultry Sci., 28, (IV), 1003-1022.

A.O.A.C. (2002). Association of Official Analytical Chemists, Washington, DC.

Bedford, M. R. and H. L.,Classen (1992).Reduction of intestinal viscosity through manipulation of dietary rye and pentosanase concentration is effected through changes in the carbohydrate composition of the intestinal aqueous phase and results in improved growth rate and feed conversion. $J$. Nutr., 560-569.

Blasco, A.; J., Ouhayoun and G. Masoero (1993). Study of rabbit meat and carcass criteria and terminology. 2nd Conference On Rabbit Production And Genetics In The Mediterranean Area, 3-7 September, Zagazig, Egypt.

Bolis, S.; C., Castrovilli; M., Rigoni; D., Tedesco and F.Luzi (1996). Effect of enzymes addition in diets on protein and energy utilization in rabbit. In Proc.; $6^{\text {th }}$ World Rabbit Congress, Toulouse, France, 111-115.

Booth, F.E. and G.E.,Wickens (1988).Non-timber uses of selected arid zone trees and shrubs in Africa. FAO Conservation Guide, pp: 92-101, Rome.

Campbell, G.L. and M. R.,Bedford (1992).Enzyme application for monogastric feeds: A review. Can. J Journal of Animal Sci., 72: 449.

Dorga, P.D. Sngh and S., Tandon(1975).Vitamin content in moringa. Journal of Current Sci., 44: 30-31.

Dougnon, T. J.; B. A., Aboh; T. M., Kpodekon and S. HonvouandI (2012).Effect of substitution of pellet of Moringa oleifera to commercial feed on rabbit's digestion, growth performance and carcass trait. . Journal of Appl. Pharmaceutical Sci., 2(9):015-019.

Duncan, D.B. (1955). Multiple Range and Multiple F-Test. Biometric, 11: 1-42.

El-Badawi, A.Y.; H.A.A., Omer; A.A. Abedo and M.H.M. Yacout (2014). Response of growing New Zealand White rabbits to rations supplemented with different levels of Moringa oleifera dry leaves. Global Veterinarian, 12(4): 573-582.

El Tazi, M.A. Safa (2012). Effect of feeding different levels of Moringa oleifera leaf meal on the performance and carcass quality of broiler chicks. Int. Journal of Sci. and Res. ISSN (online): 3.358, 2319-7064. 
Eiben, C. S.; M., N., Mézes; Zijártó; K., Kustos;K.,Gódor-Surmann and M., Erdélyi(2004).Dose-dependent effect of cellulose supplementation on performance of early-weaned rabbit. In Proc. $8^{\text {th }}$ World Rabbit Congress, Puebla, México, 799 - 804.

Fernandez, C.; J. M., Merino and R.,Carabaño (1996).Effect of enzyme complex supplementation on diets digestibility and growth performance in growing rabbits. In Proc.: $6^{\text {th }}$ World Rabbit Congress, Toulouse, France, 163-166.

Fernandez. Carmonei J.; J., Soriano; J.J., Pascual and C., Cervera (2004). The prediction of nutritive value of rabbit diets from tables of feed composition. Proceedings $8^{\text {th }}$ World Rabbit Congress, September 7-10. Puebio, Mixco,

Ibrahim, N.H.; A.S., Morsy and M.E., Ashgan (2014). Effect of Moringa peregrine seed on productive performance and hemato-biochmical parameters of growing rabbits. Journal of Animal Sci., 10 (6): 7-12.

Kristin, D., (2000). The Moringa tree. Echo technical note. Florida, U.S.A.

Luqman, S.; S., Srivastava; R. Kumar; A.K., Maurya and D., Chanda (2012). Experimental assessment of Moringa oleifera leaf and fruits for its antistress, antioxidant and scavenging potential using in vitro and in vivo assays. Research Article, Evidence-Based complementary and Alternative Medicine, 81: 12.

Mahmoud A.E.M. (2013). Effect of feeding on Moringa oleifera stems on productive performance of growing lambs. Egyptian J. Nutrition and Feeds, 16 (2) Special Issue: 281-292.

NRC (1977). National Research Council, Nutrient Requirements of Rabbits. $2^{\text {nd }}$ Rev. ed. National Academy of Sciences, Washington. D.C., USA.

Nuhu F. (2010). Effect of Moringa leaf meal on nutrient digestibility, growth, carcass and blood indices of weaner rabbits. M. Sc., Faculty of Agriculture and Natural Resources, Kwame Nkrumah University of Science and Technology, Kumasi, Ghana.

Osman, H.M.; M.E.,Shayoub; and E.M., Babiker(2012). The effect of Moringa oleifera leaves on blood parameters and body weights of Albino rats and rabbits. Jordan Journal of Bio. Sci., 5(3): 147-150.

Safwat, A.M.; Sarmiento-Franco and Santos-Ricalde, R.H. (2014). Rabbit production using local resources as feedstuffs in the tropics. Tropical and Subtropical Agroeco Systems, 17: 161-171. 
SAS (2002). Statistical Analysis System, Statistical user's Guide. Ints. Inc., Cary, $\mathrm{NC}$.

Sreelather, S. and P.R.,Padma (2009). Antioxidant activity and total phenolic content of Moringaoleifera leaves in two stages of maturity. Journal of Plant Food Human Nutri, 64: 303-311.

Sullivan, L. M. (1987). Evaluation of sorghum varieties in poultry diets. Feed Facts. Published by grain sorghum producers. Association, 4:(2). ارقام الصفحات

Talha E. Abbas (2013). The use of Moringa oleifera in poultry diets. Turkish Journal of Vet. Animal Sci., 37: 492-496.

Van Soest, P. J.; J. B., Robertson and B. A., Lewis (1991). Methods for dietary fiber, neutral detergent fiber, and non starch polysaccharides in relation to animal nutrition. Journal of Dairy Sci., 74: 2583-3597.

Zanu, H.K.; P., Asiedu; M., Tampuori and M.,Abadaand (2012). Possibilities of using moringa (Moringa oleifera) leaf meal as a partial substitute for fishmeal in broiler chickens diets. Online Journal of Anim. Feed Res., 2(1): 70-75.

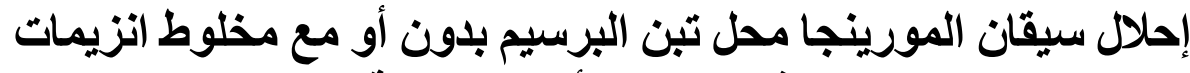

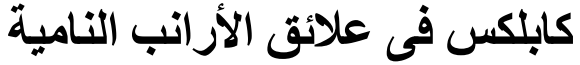

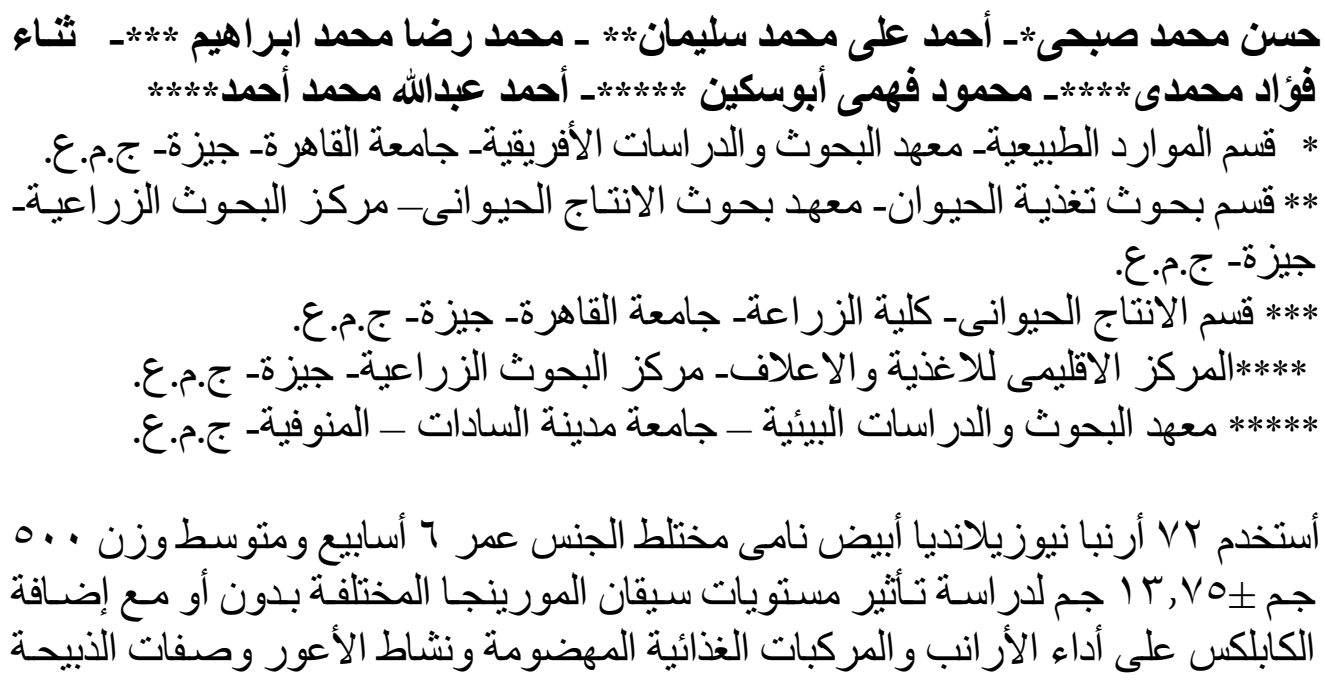


و الكفاءة الإقتصـادية. استخدم ثلاثة مستويات إستبدال من سيقان المورينجـا مـع مستوبين

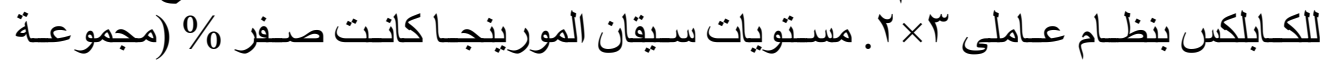

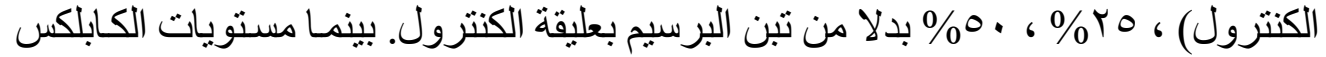

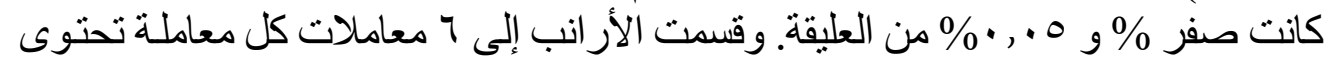

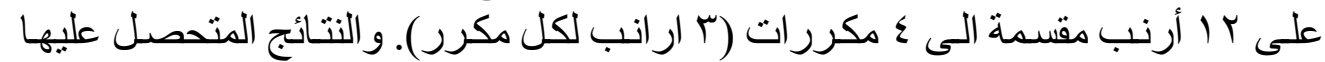

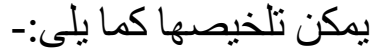

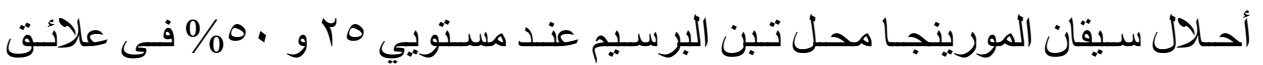

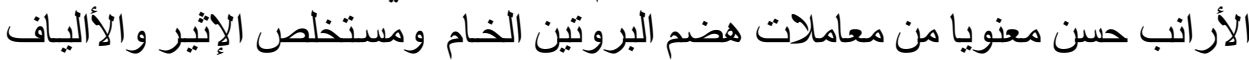

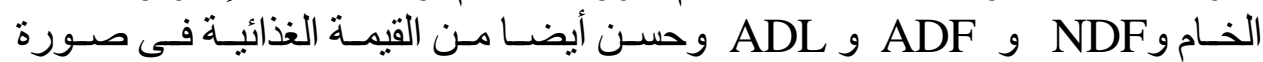

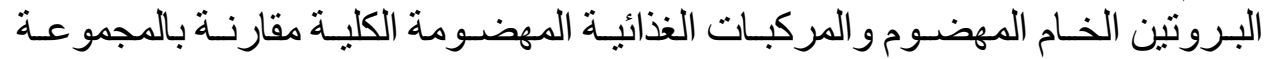

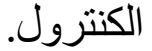

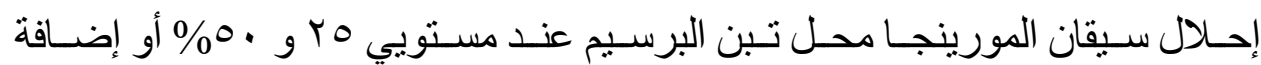

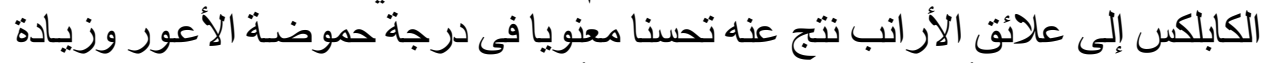
معنوية فى تركيز الأحماض الأبنانية الطنية الطيارة بالأعور.

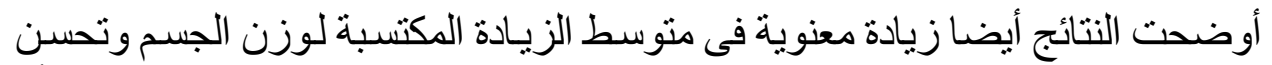

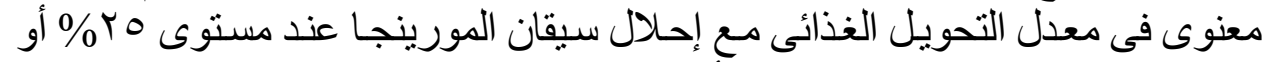
إضافه مخلوط الكابلكس الى على الائق الآر انب.

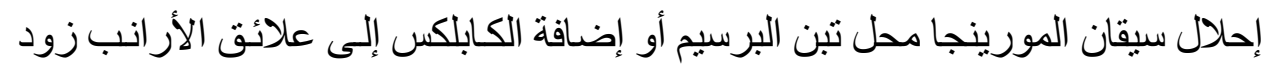

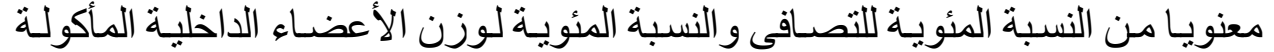

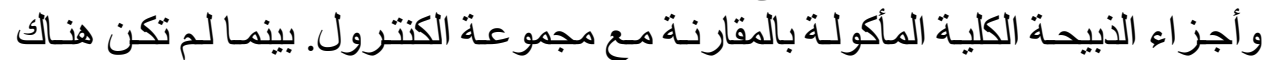

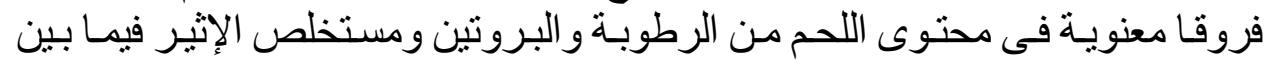
المجاميع التجريبية المختبرة المختلفة.

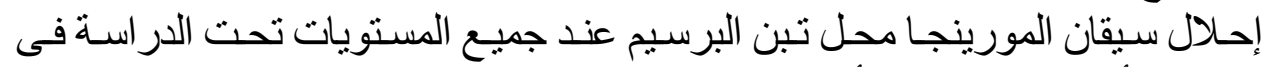
علائق الأر انب سو اء بدون أو مع إضافة الكابلكس زود من الكفاءة الاقتصادية مقارنة

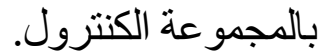
التوصية : النتائج السابقة توضح أن سيقان المورينجا يمكن إستخدامها بدلا من تبن البرسيم

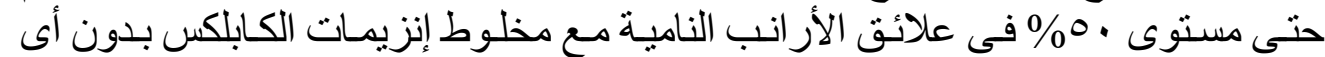
تأثير ات عكسية على مظهر النمو تحت الظروف البيئية المصرية. 